\title{
Establishment of vegetation in mine tailings using A. tumefaciens and organic matter
}

\author{
Deicy N. Sánchez ${ }^{1}$, Tony Hartshorn ${ }^{1}$, Tim McDermott ${ }^{1}$, Cathy Zabinski ${ }^{1}$, Dennis Neuman ${ }^{1}$, Stuart Jennings ${ }^{2}$, Jimy \\ Oblitas $^{3}$ \\ ${ }^{1}$ Montana State University, United States. deicysanchez@gmail.com \\ ${ }^{2}$ KC Harvey Evironmental, L, United States. \\ ${ }^{3}$ Universidad Privada del Norte, Perú. jimy.oblitas@upn.edu.pe
}

\begin{abstract}
The landscape legacy of historical metal-mining activity can persist for decades. The most frequent strategies used for the remediation of contaminated soils include: the use of synthetic membranes to isolate contaminants, direct revegetation, or lime amendments. Looking for more cost-effective bioremediation approaches, we performed a set of greenhouse studies to determine what combinations of soil amendments would lead to the best vegetative response, and potentially associated reductions in soil arsenic (As) levels. In our first greenhouse experiment, we planted Leymus cinereus (basin wildrye) in tailings, compared (after 12 weeks) plant growth, and foliar metal concentrations across treatments. Amendments included single or factorial additions of lime, 5\% organic matter $(+O M)$, and an arsenic-oxidizing (+oxbact) strain of Agrobacterium tumefaciens (Agtu). For the first experiment, only one level of OM amendment was tested (5\%) and a second greenhouse experiment with two levels of OM (1.5\% and 5\%). In this second experiment, Basin wildrye grown in soils amended with $5 \%$ OM generally did better than those grown in soils amended with $1.5 \% \mathrm{OM}$ and even better in soils amendment with 5\% OM + oxbact. These results suggest the combination of $\mathrm{OM}$ and Agtu oxbact strain could provide a potentially cost- effective approach to remediating As-contaminated soils.
\end{abstract}

Keywords-- Soil Amendments, Bacteria, Mine Tailings, Arsenic, Mining reclamation

\section{INTRODUCTION}

Thousands of acres of land have been disturbed by mining activities around the world. Soils on these lands are associated with high concentrations of heavy metals and metalloids such as arsenic, which represent a threat to human health and the environment. The presence of microbial communities in these soils can change its redox conditions, influence plant growth, increase or decrease metal toxicity, and influence metal uptake by plants.

Arsenic is found naturally in the environment at levels between 1-100 mg kg-1[1], however, antrophogenic activities such as mining in ore deposits with sulphide minerals can result in soil arsenic concentrations up to $20,000 \mathrm{mg} \mathrm{kg}^{-1}$ [2]. Arsenic is found in two states in soils: as arsenite As (III) and arsenate As (V), being As(III) the most toxic and mobile form in the environment [3].

Phytoremediation refers to the use of plants to stabilize or extract contaminants from soil or aqueous matrices [4]. For

\footnotetext{
Digital Object Identifier (DOI):

http://dx.doi.org/10.18687/LACCEI2020.1.1.175

ISBN: 978-958-52071-4-1 ISSN: 2414-6390
}

nutrient-deficient soils, phytoremediation is usually performed in combination with soil amendments to promote plant growth [5]. The use of microorganisms such as bacteria have attracted attention for their biotechnological potential to change redox conditions, improve metal removal from soils, promote plant growth and metal tolerance, or improve transfers of accumulated metals from soil to plants [6]. However, in mine tailings, amendment recommendations to promote plant establishment and growth are still lacking. The use of lime (as $\mathrm{CaCO}_{3}$ equivalents) and organic matter are believed necessary in mine tailings because of associated problems such as soil acidity, poor physical structure, low nutrient availability, toxic levels of arsenic and co-occurring heavy metals such as lead, zinc, and cadmium [7]. However, amendments such as lime, may abiotically reduce $\mathrm{As}(\mathrm{V})$ to $\mathrm{As}(\mathrm{III})$, increasing the toxicity of As to the plant [8] or they may improve plant assimilation if $\mathrm{As}(\mathrm{III})$ is oxidized to $\mathrm{As}(\mathrm{V})$, which has geochemical behavior similar to that of phosphate $\left(\mathrm{PO}_{4}\right)^{-3}$ [9], [10]. Also, other studies have shown that increase in $\mathrm{pH}$ can also mobilize soil arsenic and change arsenic speciation.

This study aims to evaluate the effect of different soil amendments (e.g. lime, om, and bacteria) and their combinations on the germination, growth and as uptake by Leymus cinereus in contaminated tailing soils.

\section{MATERIALS AND METHODS}

\subsection{Study Area}

Tailings to $0.20 \mathrm{~m}$ depth were collected from the Lampert Ranch along the upper Clark Fork near Warm Springs, area downstream of the city of Anaconda and the town of Opportunity, MT, USA. This area was placed on the National Priority List in 1983 due to metal contamination following $\sim 100$ years of copper smelting at Anaconda, approximately 20 kilometers southwest of the soil collection area [11]. Soil was transported to the Plant Growth Center (PGC) at Montana State University (MSU), homogenized, air dried, and sieved $(<2 \mathrm{~mm})$.

\subsection{Greenhouse Experiment}

Two sets of greenhouse experiments were performed using a completely randomized design. The first set of experiments included nine treatments as follows:

Single treatments: Calcium hydroxide $( \pm$ Lime), organic matter $( \pm \mathrm{OM}$ at a rate of $5 \%)$, oxidizing strain of 
Agrobacterium tumefaciens ( + Oxag), a positive control (uncontaminated soil obtained from the greenhouse or potting mix) (+control) and a negative control (unamended tailings) (Control).

Double treatments: Three combinations of two treatments included lime + OM (5\%), lime + (+Oxag) and OM (5\%)+ (+Oxag)

Triple treatment: A combination of three treatments included lime + OM (5\%) + (+Oxag).

With the best results of the first experiment, we performed a second one with 3 treatments and 10 replicates for each treatment to raise statistical power. Organic matter in each treatment was performed with two levels (1.5 and 5\%). Treatments evaluated were:

$$
\begin{aligned}
& \text { Lime + OM } \\
& \text { Lime + OM + (+Oxag) } \\
& \text { OM + (+Oxag) }
\end{aligned}
$$

Soil -amendments

Total lime requirement was determined by the Acid Base Account (ABA) test, by modified Sobek method [12] and the Shoemaker, McLean and Pratt (SMP buffer) method [11].

Lime as $\mathrm{Ca}(\mathrm{OH})_{2}$ was applied based on a calcium carbonate $\left(\mathrm{CaCO}_{3}\right)$ equivalence of $100: 136$ to otherwise unamended tailing soils. Each pot for +lime treatments contained $\sim 1900 \mathrm{~g}$ of soil including $50 \mathrm{~g}$ of $\mathrm{Ca}(\mathrm{OH}) 2$. Because the soil $\mathrm{pH}$ initially rose quite rapidly, limed tailings were allowed to equilibrate four months before additional treatments were applied or seeding occurred. Organic matter (OM; "EKO-compost-original" [Missoula, MT]) contained $1.4 \%$ nitrogen, $1.9 \%$ phosphorus (as $\left.\mathrm{P}_{2} \mathrm{O}_{5}\right) ; 0.65 \%$ potassium (as $\mathrm{K}_{2} \mathrm{O}$ ), and $0.48 \%$ magnesium. $\mathrm{OM}$ was incorporated into the soil at a rate of $5 \%$ weight ( $95 \mathrm{~g}$ per pot) or $1.5 \%$ (28 g per pot), to simulate ideal OM conditions for Montana soils, which typically range between 2 and 4\% OM. Nitrogen was added as $\mathrm{KNO}_{3}$ following the recommendations of the Natural Resources Conservation Service of 70 pounds per acre.

\subsection{Bacteria Culture}

Cultures of oxidizing strains of A. tumefaciens were obtained from the McDermott laboratory at MSU. The oxidizing strain of $A$. tumefaciens wild type is able to oxidize $\mathrm{As}(\mathrm{III})$ into $\mathrm{As}(\mathrm{V})$ at fast rates from 0.7 to $1.7 \mathrm{umol} \mathrm{d}^{-1}(0.05$ to $\left.0.12 \mathrm{mg} \mathrm{d}^{-1}\right)$ [6]. Every culture was added into the soil through a nitrate solution $\left(33.3 \mathrm{~g} \mathrm{KNO}_{3}\right.$ into $20 \mathrm{~L}$ of deionized water) at a rate of $0.6 \mathrm{~L} \mathrm{pot}^{-1}$.

\subsection{Plant Seeds}

Basin wildrye has been reported as a good candidate for revegetation in areas impacted by mining activities in the Upper Clark Fork River basin. This species can grow in soils with high total arsenic concentrations (1334 $\left.\mathrm{mg} \mathrm{kg}^{-1}\right)[13]$, which makes it a good candidate for phytoremediation. Seeds of Basin wildrye were provided by USDA NRCS Bridger
Plant Materials Center, Bozeman, Montana. Seeds were sown at a rate of 16 for the first experiment and 20 for the second experiment.

\subsection{Greenhouse Conditions}

Plants were grown in the Plant Growth Center (PGC) at MSU. Temperatures in the greenhouse were maintained at $22^{\circ} \mathrm{C}$ during the day and $20^{\circ} \mathrm{C}$ during the night. Additional lighting to extend day length to a 16 -hour, photoperiod was provided by 420 -watt high-pressure sodium lamps. Pots were rotated once per week to avoid edge/position effects. Plants grew for 12 weeks.

\subsection{Metal and Arsenic Analysis}

For arsenic foliar analyses, samples were harvested after 12 weeks. Plants were washed with tap water and rinsed with distilled water. After washing, plants were oven-dried at $60^{\circ} \mathrm{C}$ for six days, and then weighed. After drying, plant material was digested following standard methods [10]. Briefly, plants $(0.5 \mathrm{~g})$ were digested in an autoclave with $3 \mathrm{~mL} \mathrm{HNO}_{3}(67 \%)$, $2 \mathrm{~mL} \mathrm{H}_{2} \mathrm{O}_{2}(30 \%)$ and $10 \mathrm{~mL}$ deionized water at $1250 \mathrm{c}$ and $1.25 \mathrm{kPa}$ for $30 \mathrm{~min}$, filtered with Whatman paper (number 38 ), diluted to $25 \mathrm{~mL}$ with DI water, and analyzed by ICP-MS at the Center for Biofilm Engineering at MSU. Only foliar results were included in this study.

\subsection{Statistical Analysis}

Plant biomass, germination, and heavy metal concentration data were analyzed using Software Minitab 17 Statistical. In cases where data were not distributed normally, natural logarithmic transformations were necessary (e.g., biomass, arsenic concentration and metal uptake). All these transformations were applied using rounded lambda values from a Box-Cox function (Software Minitab 17 Statistical 2010). Treatments differences were tested by employing oneway analysis of variance (ANOVA) for the first experiment and two way analysis of ANOVA for the second experiment; statistically significant results are reported for $\mathrm{P}$ value $<0.05$. Means were compared using Fisher's least significant difference (LSD) method $(\mathrm{P}<0.05)$.

\section{RESULTS AND DISCUSSION}

\subsection{Tailing Characterization}

Arsenic concentrations ranged from 1080 to $3600 \mathrm{mg} \mathrm{kg}^{-1}$ (35-115 fold higher than typical background levels of the area [11]. Total metal concentrations of $\mathrm{Cu}, \mathrm{Pb}$, and $\mathrm{Zn}$ were also elevated in comparison with background soils. Tailings soils presented low $\mathrm{pH}$ (the average of 10 samples measured with a 1:2 solution of soil: deionized water was 3.86) allowing for increasing of metal solubility, which can lead to phytotoxic conditions for plants [14]. With these soil characteristics, the establishment of natural revegetation in these areas is quite limited; therefore, revegetation must be assisted using 
techniques to promote plant growth. Studies to promote plant growth in Anaconda have been conducted since at least 1946 [11], however, there is always interest in less expensive alternatives for increased establishment of vegetation in these types of heavily contaminated soils.

\subsection{Greenhouse Study: Germination}

The last germination in the first experiment occurred after 20 days, no germination of Basin wildrye seeds was observed in negative control. Seeds in tailings amended only with oxidizing A. tumefaciens bacteria reached a mean of $25 \%$ (Figure 1). The other treatments did not show statistical differences in germination; however, we observed differences in survival, growth and plant health. The best responses were observed in treatments such as $+\mathrm{OM}+(+\mathrm{Oxag})(72 \%),+\mathrm{OM}$ $(69 \%)$ that is the reason which we performed a second experiment.

The last germination in the second experiment occurred after 18 days. There were not differences between treatments but the two percentage of organic matter showed significant differences in germination effects. All treatments including $5 \%$ OM resulted in the highest percentage of germination $(\sim 60 \%)$. the only treatment with $1.5 \%$ OM that was not statistically different from treatments described previously was OM 1.5\% (+Oxag) (54\%). Treatments, which included $1.5 \%$ of OM, reached: OM $1.5 \%+(+\mathrm{Oxag})(54 \%)$, lime + OM $1.5 \%+(+\mathrm{Oxag})(50 \%)$ and were not statistically different. Finally, we obtained $45 \%$ of germination in lime+ OM $1.5 \%$ treatment (Figure 2).

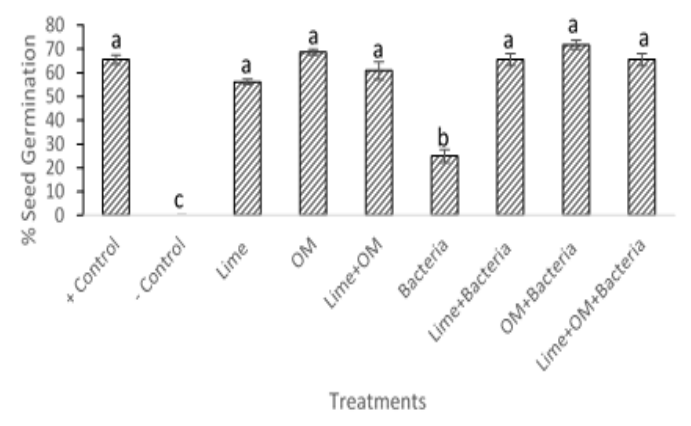

Fig.1. Percentage of seed germination of basin wildrye in a greenhouse experiment (means $\pm \mathrm{SE}$ ) using different types of amendment. OM=organic matter 5\%, Means with same letter are not statistically different

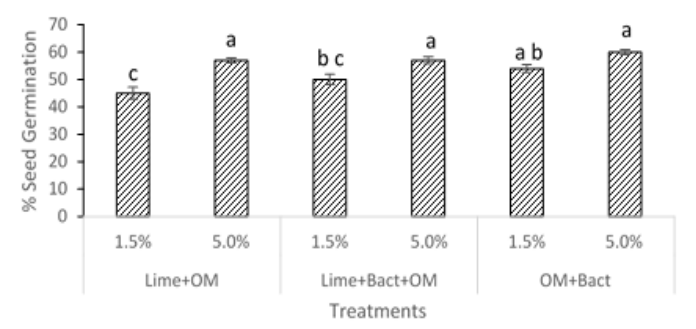

Fig.2. Germination of basin wildrye in the second greenhouse experiment (means $\pm \mathrm{SE}$ ). Means with same letter are not statistically different.
Germination in many treatments can be explained by the increased soil $\mathrm{pH}$, which is a result of the addition of lime; this may have increased nutrient availability from organic matter and/or decreased metal bioavailability.[15]

In the first experiment poor germination could be the result of the high concentrations of metals present in the soil, which we estimated as $2367 \mathrm{mg} \mathrm{As} \mathrm{kg}^{-1}$ (as well as $5673 \mathrm{mg}$ $\mathrm{Cu} \mathrm{kg}^{-1}, 1115 \mathrm{mg} \mathrm{Pb} \mathrm{kg}{ }^{-1}$, and $1913 \mathrm{mg} \mathrm{Zn} \mathrm{kg}{ }^{-1}$ ), the low $\mathrm{pH}$ (3.86), and/or the lack of nutrients.

In the second experiment, the relatively high germination in treatments with 5\% OM and lime: could have been associated with soil $\mathrm{pH}$ increase, better structure and nutrients provided by lime and OM. In addition OM could have reduced the availability of metals by changing these from bioavailable forms to less-available forms in the fractions associated with organic matter, metal oxides, or carbonates[16], [17]

\subsection{Greenhouse Study-Plant Biomass Production}

Biomass production in the first experiment varied widely depending on treatment. As expected, the uncontaminated soil (positive control) had the highest biomass. No detectable biomass was produced in unamended tailings and in pots amended with just bacteria. The greatest biomass production was observed in the positive control and combination of lime $+\mathrm{OM}+$ (+Oxag) (3.4 and $3.3 \mathrm{~g} \mathrm{pot}^{-1}$, respectively), which were not statistically different. The addition of $\mathrm{OM}+$ lime or the use of just OM yielded intermediate levels of aboveground biomass (0.5 and $0.1 \mathrm{~g} \mathrm{pot}^{-1}$, respectively) and the lowest biomass production was observed in treatments of Lime + (+Oxag) and Lime (0.03 $\mathrm{g} \mathrm{pot}^{-1}$ and $0.02 \mathrm{~g} \mathrm{pot}^{-1}$ respectively) (Figure 2).

Plant biomass in the second experiment differed between treatments as well with levels of OM. Plants were larger grown with 5\% OM than $1.5 \%$ OM. The two-way analysis of variance showed significant differences between treatments and OM $(\mathrm{p}=0.000)$. Treatments which included Lime $+\mathrm{OM}$ $5 \%\left(0.51 \mathrm{~g} \mathrm{pot}^{-1}\right)$ and $\mathrm{OM} 1.5 \%+(+\mathrm{Oxag})\left(0.67 \mathrm{~g} \mathrm{pot}^{-1}\right)$ were not statistically different. The lowest biomass responses were observed in treatments of Lime + (+Oxag) + OM 1.5\% $(0.15 \mathrm{~g}$ pot -1$)$ and Lime + OM $1.5 \%\left(0.15\right.$ g pot $\left.^{-1}\right)$ (Figures 3 and 4$)$.

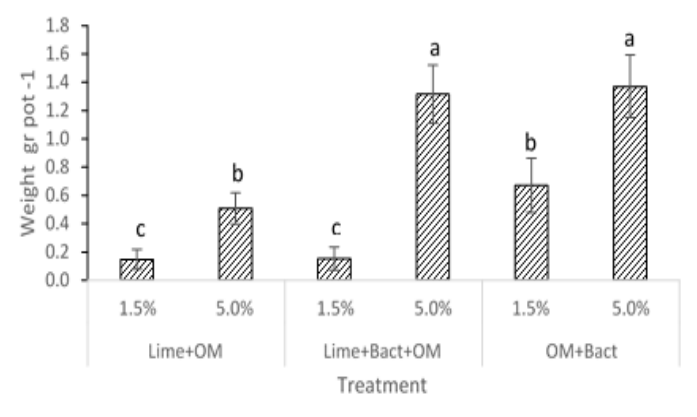

Fig.3. Shoot biomass for the first experiment in 12 weeks after seeding. Means with the same letter are not statistically different $(\mathrm{P}>0.05)$. 


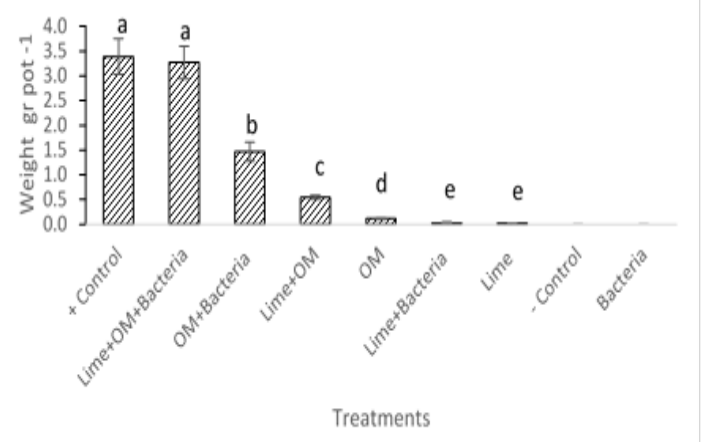

Fig.4. Shoot biomass for the second experiment in 12 weeks after seeding. Means with the same letter are not statistically different $(\mathrm{P}>0.05)$.

Concerning the first experiment, the results suggest that $\mathrm{OM}$ additions could have lowered solubility and mobility of the arsenic [18]-[20]. Low plant biomass was registered in soils amended just with Lime $\left(0.02 \mathrm{~g} \mathrm{pot}^{-1}\right)$ or with Lime + (+Oxag) $\left(0.03 \mathrm{~g} \mathrm{pot}^{-1}\right)$. These results imply the addition of just lime is not as effective on plant biomass in these soils. Thus, it is possible that lime may have increased As(III) and/or As mobility [21], [22]. Generally, plant benefit appears most pronounced when oxidizing strains of $A$. tumefaciens are present in combination with OM. To the best of our knowledge, this is one of the few reports quantifying plant growth outcomes on tailings as a function of amendments including bacterial strain inoculation. Thus, treatments combining organic matter and bacteria could have had a synergistically advantageous effect on biomass production, with the bacteria, which could act as arsenic-tolerant plant growth-promoting bacteria (PGPB).

Significant differences were observed in the second experiment with different levels of OM. (Figure 4). High levels $(5 \%)$ of OM resulted in higher biomass production. The presence of oxidizing bacteria greatly increased plant biomass showing that the presence of lime is not required to achieve this result when this bacteria is combined with 5\% OM. [23] showed that inoculation with rhizobacteria generally produces larger aboveground biomass and alters metal availability in the soil. Several studies have shown the use of different bacteria able to enhance plant biomass [24], [25]. However, little information is available regarding the mechanisms by which microbes enhance phytoremediation and biomass in combination with amendments.

In our study, the addition of $A$. tumefaciens could have accelerated redox reactions in the soil, which helped the uptake of the less toxic arsenic form (AsV) by the plant. As a result, there may have been less growth inhibition in the plants as observed in treatment of $\mathrm{OM}+(+\mathrm{Oxag})$. If As (III) is oxidized to $\mathrm{AsV}$, arsenic assimilation by a plant can be improved, because $\mathrm{As}(\mathrm{V})$ has geochemical behavior similar to phosphate (PO4)-3. [26]

\subsection{Arsenic Concentration in Plants}

In the first experiment we can observe that the maximum arsenic concentrations in Basin wildrye occurred in soils amended with lime $+(+$ Oxag $)\left(31.1 \mathrm{mg} \mathrm{kg}^{-1}\right)$, which was not statistically different from concentrations observed in soils amended with just Lime (25.8 $\left.\mathrm{mg} \mathrm{kg}^{-1}\right)$ and just OM (20.9 mg $\mathrm{kg}-1)$. Intermediate arsenic concentrations in Basin wildrye were recorded for soils amended with $\mathrm{OM}+$ bacteria $(14.7 \mathrm{mg}$ $\left.\mathrm{kg}^{-1}\right)$ or lime $+\mathrm{OM}+$ bacteria treatment $\left(13.2 \mathrm{mg} \mathrm{kg}^{-1}\right)$. The lowest arsenic concentration was observed either in the lime + OM treatment $\left(8.4 \mathrm{mg} \mathrm{kg}^{-1}\right)$ or in the uncontaminated soil positive control treatment $\left(1.1 \mathrm{mg} \mathrm{kg}^{-1}\right)$. (Figure 5).

In the second experiment arsenic concentration in Basin wildrye shoots varied between levels of OM. Thus, treatments with $1.5 \% \mathrm{OM}$ concentrated more arsenic than treatments with $5 \%$ OM. Plants grown in soils amended with +lime + OM $1.5 \%+(+$ Oxag $)$ and \pm lime + OM $1.5 \%$ had the highest arsenic concentrations (49.9 and $29.6 \mathrm{mg} \mathrm{kg}^{-1}$, respectively). The lowest shoot As concentrations were unexpectedly associated with plants grown in soils amended with OM $5 \%$.Concentrations ranging from $8.4 \mathrm{mg} \mathrm{kg}^{-1}$ ( \pm (lime $+\mathrm{OM}$ $5 \%)$ to $17.8 \mathrm{mg} \mathrm{kg}^{-1}(\mathrm{OM} \mathrm{1.5 \%}+(+\mathrm{Oxag}))$. (Figures 5 and 6$)$

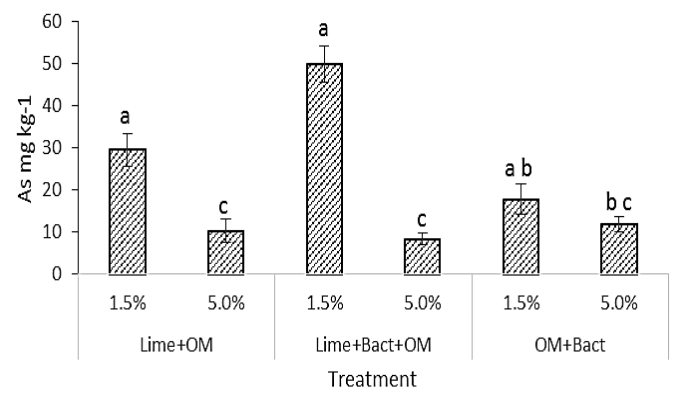

Fig. 5. Total arsenic concentrations (mg kg-1) in basin wildrye shoots after 12 weeks, in the first experiment. Means with the same letter are not statistically different $(\mathrm{P}>0.05)$.

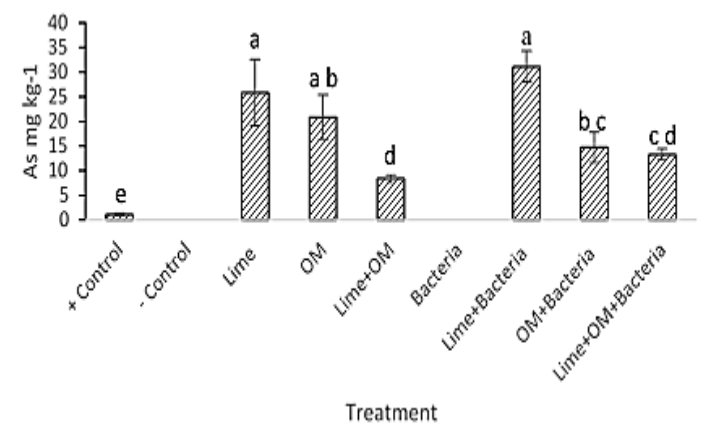

Fig. 6. Total arsenic concentrations (mg kg-1) in basin wildrye shoots after 12 weeks, in the second experiment. Means with the same letter are not statistically different $(\mathrm{P}>0.05$.

The maximum value of arsenic accumulation in basin wildrye shoots previously reported was $16.5 \mathrm{mg} \mathrm{kg}^{-1}$ [27], [28] 
and the maximum shoot concentration we observed in the first greenhouse was about $47 \%$ greater. Other experiments have been conducted in soils with either lower arsenic concentrations ( $15 \mathrm{mg} \mathrm{kg}^{-1}$ vs this study's average of $\sim 1.100$ $\mathrm{mg} \mathrm{kg-1)} \mathrm{[29]} \mathrm{or} \mathrm{with} \mathrm{a} \mathrm{greater} \mathrm{focus} \mathrm{on} \mathrm{arsenic}$ concentrations in soils than in plant biomass [30]. Therefore, comparisons are very restricted. However, it is important to highlight that all the plants that grew in our treatments did not exceed the maximum tolerable dietary intake threshold of arsenic for livestock $\left(50 \mathrm{mg} \mathrm{kg}^{-1}\right)$ recommended by United States, Australian and New Zealand guidelines [31].

Results in the second experiment were varied, specifically in treatments + Lime + OM $1.5 \%+(+$ Oxag $)$ and \pm lime + OM $1.5 \%$. These had the highest arsenic concentrations, despite it contained a low percentage of organic matter, but probably the presence of lime could have influenced it, as lime may have increased As(III) and/or As mobility. General approaches to cope with harsh mine soil conditions typically include the use of lime (as $\mathrm{CaCO}_{3}$ equivalents) and organic matter amendments that are believed necessary to address the problems associated with mine soils.

It is important evaluate the complex compost and As interaction in As contaminated soil. For restoration and remediation of As contaminated soil, the application of compost or other organic amendments need a careful optimization. Results revealed that, in Narwala (sandy loam) soil, the addition of compost decreased shoot As concentration of maize plants ( $\mathrm{p}<0.05 ; 4.01-13.7 \mathrm{mg} \mathrm{kg} \mathrm{kg}^{-1}$ dry weight (DW)) and biomass weight decreases with increasing levels of As in the absence of compost [20]. These amendments can reduce the availability of most of the metals; however, in the particular case of arsenic they can unfortunately increase its availability and toxicity.

This makes the lime or lime + bacteria treatments less desirable for cost-effective revegetation purposes. Our results clearly show that the use of OM + bacteria has enhanced Basin wildrye growth. Other studies have shown the same results with just bacterial inoculation for different metals. For example, [32] showed that in soils contaminated with $\mathrm{Cd}(8$ $\left.\mathrm{mg} \mathrm{L}^{-1}\right)$, inoculation with the bacterium Burkholderia cepacia enhanced shoot and root biomass (54\% and $46 \%$, respectively) in the Sedum alfredii plant. Using the same bacteria and plant, shoot biomass was enhanced by $110 \%$ when it was exposed to $\mathrm{Zn}\left(8 \mathrm{mg} \mathrm{L}^{-1}\right)$, which resulted also in a $\mathrm{Cd}$ and $\mathrm{Zn}$ uptake increase of $243 \%$ and $96.3 \%$, respectively. [25] reported that the use of Agrobacterium radiobacter lowered soil arsenic concentrations by $54 \%$ versus $43 \%$ for un-inoculated soils,

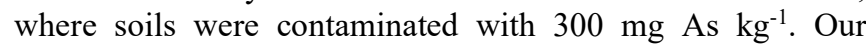
findings demonstrate that the combination of organic matter and bacteria plays an important role in growth, accumulation and arsenic resistance in plants that can grow directly in tailings soils; moreover, our results can lead us to new techniques that can help to improve phytoremediation outcomes.

Analyzing results of the second experiment and as a general conclusion, the application of $A$. tumefaciens oxidizing strain in two cases significantly increased arsenic uptake in Basin wildrye (Figure 5). There are very few studies reporting arsenic concentrations in Basin wildrye grown on tailings, thus the comparisons are very limited

In this study, we reported the highest arsenic uptake by pot with a mean of $0.016 \mathrm{mg} \mathrm{As}$ pot $^{-1}$ in 12 weeks of basin wildrye growth. [29] reported an average arsenic uptake by basin wildrye after 16 weeks with 4 plants pot $^{-1}$ of $0.04 \mathrm{mg}$ pot $^{-1}$ when plants were exposed to $50 \mathrm{mg} \mathrm{kg}^{-1}$ arsenic and up to $15 \mathrm{mg} \mathrm{kg}^{-1}$ phosphorus (our unamended tailings -soils averaged $2367 \mathrm{mg} \mathrm{kg}^{-1}$ total arsenic and $\sim 1000 \mathrm{mg} \mathrm{kg}^{-1}$ phosphorus $\left[0.23 \% \mathrm{P}_{2} \mathrm{O}_{5}\right]$ ). Other researchers found that a contaminated soil by heavy metals ( $\mathrm{Fe}, \mathrm{Cu}, \mathrm{Mn}$ and $\mathrm{Zn}$ ) can be removed adding organic matter. In either case, the use of A. tumefaciens oxidizing strain in combination with organic matter seems to be a promising, inexpensive, and innovative technique that can be used in areas affected by arsenic.

As a final point, the two experiments results suggested the potential for phytoremediation success from our bacterial inoculation in combination with the highest level of organic matter $(5 \%)$.

\section{CONCLUSIONS}

Our greenhouse studies showed an important and positive effect of organic matter in germination of basin wildrye. Higher levels of organic matter shows better results in germination, biomass and arsenic uptake. The combination of $\mathrm{OM}$ and bacteria leaded important positive effects above the conventional mining reclamation amendments.

\section{ACKNOWLEDGMENT}

This work was funded by Association Los Andes Cajamarca, the Fulbright Commission, and the department of Land Resource and Environmental Science at Montana State University. We are grateful to the USDA NRCS Bridger Plant Materials Center, Bozeman, Montana and all the people that helped in this study.

\section{REFERENCES}

[1] B. M. Dahal, M. Fuerhacker, A. Mentler, R. R. Shrestha, y W. E. H. Blum, «Screening of arsenic in irrigation water used for vegetable production in Nepal», Arch. Agron. Soil Sci., vol. 54, n. ${ }^{\circ}$ 1, pp. 41-51, feb. 2008, doi: 10.1080/03650340701628197.

[2] A. Garcia-Sanchez y E. Alvarez-Ayuso, «Arsenic in soils and waters and its relation to geology and mining activities (Salamanca Province, Spain)», J. Geochem. Explor., vol. 80, n. ${ }^{\circ}$ 1, pp. 69-79, 2003, doi: 10.1016/S0375-6742(03)00183-3.

[3] P. K. Rai, K.-H. Kim, S. S. Lee, y J.-H. Lee, «Molecular mechanisms in phytoremediation of environmental contaminants and prospects of engineered transgenic plants/microbes», Sci. Total Environ., vol. 705, 2020, doi: 10.1016/j.scitotenv.2019.135858.

[4] A. Dradrach, A. Karczewska, y K. Szopka, «Arsenic accumulation by red fescue (Festuca rubra) growing in mine affected soils - Findings from the field and greenhouse studies», Chemosphere, vol. 248, 2020, doi: 10.1016/j.chemosphere.2020.126045. 
[5] E. Lebrun et al., «Arsenite oxidase, an ancient bioenergetic enzyme», Mol. Biol. Evol., vol. 20, n. ${ }^{\circ}$ 5, pp. 686-693, 2003, doi: 10.1093/molbev/msg071.

[6] R. E. Macur, C. R. Jackson, L. M. Botero, T. R. McDermott, y W. P. Inskeep, «Bacterial Populations Associated with the Oxidation and Reduction of Arsenic in an Unsaturated Soil», Environ. Sci. Technol., vol. 38, n. ${ }^{\circ} 1$, pp. 104-111, 2004, doi: 10.1021/es034455a.

[7] A. Bradshaw, «Restoration of mined lands - using natural processes», Ecol. Eng., vol. 8, n. ${ }^{\circ} 4$, pp. 255-269, ago. 1997, doi: 10.1016/S09258574(97)00022-0.

[8] L. Lei, G. Zhang, J. Lin, X. Wang, S. Wang, y Y. Jia, «Co-adsorption of arsenite and arsenate on mixed-valence Fe(II,III) (hydr)oxides under reducing conditions», Appl. Geochem., vol. 98, pp. 418-425, nov. 2018, doi: 10.1016/j.apgeochem.2018.10.015.

[9] A. A. Meharg y M. R. Macnair, «Suppression of the High Affinity Phosphate Uptake System: A Mechanism of Arsenate Tolerance in Holcus lanatus L.», J. Exp. Bot., vol. 43, n. ${ }^{\circ} 4$, pp. 519-524, abr. 1992, doi: $10.1093 / \mathrm{jxb} / 43.4 .519$.

[10] E. Moreno Jiménez, Plant-based methods for remediating arsenicpolluted mine soils in Spain = Recuperación de suelos mineros contaminados con arsénico mediante fitotecnologías. 2010.

[11] D. R. Neuman, G. S. Vandeberg, P. B. Blicker, J. D. Goering, S. R. Jennings, y K. Ford, «Phytostabilization of acid metalliferous mine tailings at the Keating Site in Montana», presentado en 22nd American Society of Mining and Reclamation Annual National Conference 2005, 2005, vol. 2, pp. 791-806.

[12] H. Bouzahzah, M. Benzaazoua, B. Plante, y B. Bussiere, «A quantitative approach for the estimation of the "fizz rating" parameter in the acid-base accounting tests: A new adaptations of the Sobek test», J. Geochem. Explor., vol. 153, pp. 53-65, 2015, doi 10.1016/j.gexplo.2015.03.003.

[13] T. N. Martin, «Emergence and growth of seven grass species across a gradient of metals and arsenic in lime-amended contaminated soils», Thesis, Montana State University - Bozeman, College of Agriculture, 2009.

[14] F. F. Munshower, Practical Handbook of Disturbed Land Revegetation. CRC Press, 2018.

[15] S. Brown, A. Svendsen, y C. Henry, «Restoration of High Zinc and Lead Tailings with Municipal Biosolids and Lime: A Field Study», $J$. Environ. Qual., vol. 38, n. ${ }^{\circ}$ 6, pp. 2189-2197, nov. 2009, doi: 10.2134/jeq2008.0103.

[16] M. Sabir, A. Ali, M. Zia-Ur-rehman, y K. R. Hakeem, «Contrasting Effects of Farmyard Manure (FYM) and Compost for Remediation of Metal Contaminated Soil», Int. J. Phytoremediation, vol. 17, n. ${ }^{\circ}$ 7, pp. 613-621, jul. 2015, doi: 10.1080/15226514.2014.898019.

[17] D. J. Walker, R. Clemente, y M. P. Bernal, «Contrasting effects of manure and compost on soil $\mathrm{pH}$, heavy metal availability and growth of Chenopodium album L. in a soil contaminated by pyritic mine waste», Chemosphere, vol. 57, n. ${ }^{\circ} 3$, pp. $215-224$, oct. 2004 , doi: 10.1016/j.chemosphere.2004.05.020.

[18] X. Cao y L. Q. Ma, «Effects of compost and phosphate on plant arsenic accumulation from soils near pressure-treated wood», Environ Pollut., vol. 132, n. ${ }^{\circ} 3$, pp. 435-442, dic. 2004, doi: 10.1016/j.envpol.2004.05.019

[19] J. Ma et al., «Reduction, methylation, and translocation of arsenic in Panax notoginseng grown under field conditions in arseniccontaminated soils», Sci. Total Environ., vol. 550, pp. 893-899, abr. 2016, doi: 10.1016/j.scitotenv.2016.01.188.

[20] T. Mehmood et al., «Effect of compost addition on arsenic uptake, morphological and physiological attributes of maize plants grown in contrasting soils», J. Geochem. Explor., vol. 178, pp. 83-91, jul. 2017, doi: 10.1016/j.gexplo.2017.03.018.

[21] W. J. Fitz y W. W. Wenzel, «Arsenic transformations in the soilrhizosphere-plant system: fundamentals and potential application to

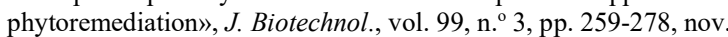
2002, doi: 10.1016/S0168-1656(02)00218-3.

[22] W. Pan, C. Wu, S. Xue, y W. Hartley, «Arsenic dynamics in the rhizosphere and its sequestration on rice roots as affected by root oxidation», J. Environ. Sci., vol. 26, n. ${ }^{\circ} 4$, pp. 892-899, abr. 2014, doi: 10.1016/S1001-0742(13)60483-0.
[23] S. C. Wu, K. C. Cheung, Y. M. Luo, y M. H. Wong, «Effects of inoculation of plant growth-promoting rhizobacteria on metal uptake by Brassica juncea», Environ. Pollut., vol. 140, n. ${ }^{\circ}$ 1, pp. 124-135, mar. 2006, doi: 10.1016/j.envpol.2005.06.023.

[24] B. Román-ponce et al., «Plant Growth-Promoting Traits in Rhizobacteria of Heavy Metal-Resistant Plants and Their Effects on Brassica nigra Seed Germination», Pedosphere, vol. 27, n. ${ }^{\circ} 3$, pp. 511 526, jun. 2017, doi: 10.1016/S1002-0160(17)60347-3.

[25] Q. Wang, D. Xiong, P. Zhao, X. Yu, B. Tu, y G. Wang, «Effect of applying an arsenic-resistant and plant growth-promoting rhizobacterium to enhance soil arsenic phytoremediation by Populus deltoides LH05-17», J. Appl. Microbiol., vol. 111, n. ${ }^{\circ}$ 5, pp. $1065-$ 1074, nov. 2011, doi: 10.1111/j.1365-2672.2011.05142.x.

[26] E. Moreno-Jiménez, E. Esteban, y J. M. Peñalosa, «The fate of arsenic in soil-plant systems», Rev. Environ. Contam. Toxicol., vol. 215, pp. 1-37, 2012, doi: 10.1007/978-1-4614-1463-6 1 .

[27] J. Gil-Loaiza et al., «Phytostabilization of Mine Tailings Using Compost-Assisted Direct Planting: Translating Greenhouse Results to the Field», Sci. Total Environ., vol. 565, pp. 451-461, sep. 2016, doi: 10.1016/j.scitotenv.2016.04.168.

[28] D. Neuman y K. Ford, «Phytostabilization as a Remediation Alternative at Mining Sites», US Bur. Land Manag. Pap., ene. 2006.

[29] J. A. Knudson, T. Meikle, y T. H. DeLuca, «Role of mycorrhizal fungi and phosphorus in the arsenic tolerance of basin wildrye», J. Environ. Qual., vol. 32, n. ${ }^{\circ}$ 6, pp. 2001-2006, dic. 2003, doi: $10.2134 /$ jeq2003.2001

[30] T. C. Tafi, «Reclamation effectiveness at three reclaimed abandoned mine sites in Jefferson County, Montana», Thesis, Montana State University - Bozeman, College of Agriculture, 2006

[31] D. Mains, D. Craw, C. G. Rufaut, y C. M. S. Smith, «Phytostabilization of Gold Mine Tailings from New Zealand. Part 2: Experimental Evaluation of Arsenic Mobilization During Revegetation», Int. J. Phytoremediation, vol. 8, n. ${ }^{\circ}$ 2, pp. 163-183, jul. 2006, doi: 10.1080/15226510600742559.

[32] W. C. Li, Z. H. Ye, y M. H. Wong, «Effects of bacteria on enhanced metal uptake of the $\mathrm{Cd} / \mathrm{Zn}$-hyperaccumulating plant, Sedum alfredii», J. Exp. Bot., vol. 58, n. ${ }^{\circ}$ 15-16, pp. 4173-4182, 2007, doi: $10.1093 / \mathrm{jxb} / \mathrm{erm} 274$ 